\title{
On the Traditional Attitude Towards Architectural Innovation
}

\author{
Igor A. Bondarenko ${ }^{1, *}$
}

\begin{abstract}
${ }^{1}$ Scientific Research Institute of the Theory and History of Architecture and Urban Planning, Branch of the Central Institute for Research and Design of the Ministry of Construction and Housing and Communal Services of the Russian Federation, Moscow, Russia

*Corresponding author. E-mail: 4423353@mail.ru
\end{abstract}

\begin{abstract}
Along with all the traditionalism of ancient cultures, there was also a place for seeking innovation. History reveals more or less significant changes in the planning and development of settlements, which took place for various reasons. It is important for us to be able to distinguish the changes forced by natural disasters and conquests from systematic, predetermined by cultural traditions themselves, with their inner cycles of formation, dying and revival. The report provides an analysis of these cycles, which explain the ambiguous attitude towards the old and new in the same culture.
\end{abstract}

Special attention will be paid to the system of inheritance called "Minorat", or "Junior Right", according to which older sons had to resettle in new places. Knyazes and Tsars also moved their residences and rebuilt palaces, which was a tradition that needs to be studied.

The idea formulated in Domostroy to constantly fight against the dilapidation of the household in the name of maintaining its "eternal youth", is of particular interest, allowing to draw parallels with the image of Paradise.

It is known that the people who lived by the "old rules" avoided innovations and strangers. However, they were also peculiar to the traditions of hospitality, and travel to distant countries from which one could bring something miraculous. From that perspective, it is supposed to study the phenomenon of the extraordinary decorativism of the architecture of pre-Petrine Moscow, which caused controversial opinions of contemporaries. Some pretentiously claimed that the city "grows and rejuvenates", while others saw the "devilish motley" in that.

\section{Keywords: architectural innovation, Minorat, Domostroy, architecture of pre-Petrine Moscow}

\section{INTRODUCTION}

Traditional cultures are known for their conservatism. This can be explained by their inner consistency, self-completeness, and individuality. All the life cycles from birth to death were strictly regulated and ritualized in those cultures. Their architecture blended organically with the system of regulations and rituals and stood on guard of the Godestablished order. Therefore, that aspiration to novelty and originality which is peculiar to our time could not be manifested there.

*Fund: This paper was funded by the Program of Fundamental Researches of the Ministry of Construction, Housing and Utilities of the Russian Federation and the Russian Academy of Architecture and Construction Sciences 2020, the Research Project 1.4.5.
At the same time, innovations appeared. Buildings were rebuilt, villages and towns grew, their planning structures changed, new architectural accents appeared, foreign architectural models were brought in and took root. It is important for us to be able to distinguish between forced changes associated with natural disasters and conquests from systematic ones, predetermined by the cultural traditions themselves, which, despite their stability, were not stiff and lifeless.

The purpose of this article is to reveal the specificity of the attitude to novelty within the framework of the traditional, self-sufficient and self-replicating architectural and urban planning culture, which resisted changes. This is important for a better understanding of the vitality of many traditions, their regenerative and adaptive potential, revealing their positive properties in the situation of crisis and revolution. It is also important 
to understand how the cyclical reproduction of the stages of formation, growth, withering, dying and rebirth inherent in traditional cultures has encountered and interacted with the monotheistic religion's view of history as a unidirectional linear process.

These issues have been addressed in various scientific works, but in general, they remain poorly researched. I don't claim to have exhausted these topics in a short article, but I just want to share some of my observations and interpretations concerning their essence with readers.

\section{UPDATING WITHIN THE TRADITION}

An unchanging tradition allowed for certain changes caused by the emergence of something new that needed to be adapted. First of all, it concerned the birth of a child, who was at first dangerous for the reason of its otherworldliness, but gradually socializing, adopting the culture and becoming a full member of a community [1]. New buildings also, merging into the existing space, caused anxiety, and then later being inhabited, became quite "local", traditional. There were customs of "repairing" infants, especially the unhealthy ones, and their symbolic "re-baking" or "re-birth" [1]. There were also very difficult and painful rites of initiation in ancient times, which were considered necessary for the transformation of boys and girls into adults [2]

Something similar happened to new buildings, which always needed some finishing, adaptation, and inhabitation. The physical novelty of the building, as well as the youth of a man, was valued only to a certain extent. Once born, the new creature was to grow, mature and gain strength. It is known how differently the value of the life of a mature man, a teenager, and a baby was perceived. The people's attitude to trees gave a direct analogy to it: it was believed that a big mighty tree should never be cut down as its spirit would cruelly punish a woodcutter [3]. Such a tree deserved the right to die "a natural death". A small undergrowth was quite another matter.

The elders held powerful positions in a patriarchal society. However, the decrepit elders retired. And those, who "lived too long in the world" were treated with fear, as they were "eating someone else's time" and the earth would not want to accept them for a reason [1]. Everything in life has to have its time - both people and houses. One ethnographic source, as the reason for the big fire in the village, named the dilapidated houses: they have lived out their time - a hundred years, and the time has come to move them to a new place [4].

Most often, old houses were not destroyed but repaired and renovated. Apparently, it was believed that they, like old trees, should live up to their natural death - from fire, water or storm. It was the old, big trees that became sacred, they were protected and strengthened, if necessary. Just like old buildings, especially cult ones, "praised" by many generations, they were maintained as symbols of eternity. And yet, sometimes, these buildings had to be replaced by new ones.

It is appropriate to note the ancient tradition to displace and even kill weakened tsars, unable to protect their state from troubles. Russian fairy tales have saved this phenomenon for us: the old tsar intends to kill Ivan Tsarevich in a boiling caldron, but the latter jumps out of there young and safe. The old man who envied him does not succeed and dies without causing pity to those present. Everyone praises the new ruler. It should be noted that the young hero, having passed this test, grows up, becomes a man, worthy of the royal title.

The king's power was considered divine, and thus immutable, eternal. However, its earthly bearers were to be replaced, rejuvenated. According to the abovementioned ancient tradition, the right for the throne was granted by a marriage to a royal daughter. At a later time, when the system of inheritance called "Minorat" or "Junior Right" prevailed, the inheritance system was organized differently. According to this system, eldest sons, having families, had to resettle, exploring new lands and building their new estates there. Thus, they became the ancestors of new genealogical branches, while the parents' household was inherited by the youngest of their sons. It should be also said that in the patriarchal society there was a system of the transition of power from brother to brother and only after the death of the last of them - to sons and nephews in accordance with their seniority. The Grand Duchy of Moscow, which adopted the Byzantine system of "Majorat", that is, the inheritance from father to the eldest son, has put the end to this tradition in Russia.

It is necessary to keep in mind all the above-listed inheritance rights and duties for clarification of the reasons for the preservation of old and occurrence new in traditional society's architecture and town planning. The resettlement of young families meant the systematic emergence of more and more new points of growth of the original clan's ancestral home while keeping a relatively stable size of the fathers' home. This was akin to the ancient Greek principle of preserving the specific proportional relations between the city and its land by sending some citizens as colonists to new remote areas.

Knyazes and tsars were certainly engaged in the construction of new residences. Obviously, they were supposed to renew their residences in order to demonstrate the milestones of the growth of their genealogical tree. If the new ruler stayed to live in the old palace, he necessarily performed its repair and at least partial reconstruction. There were occasions, as it is known, to move the capitals of states to new cities. 
Consequently, the tradition itself during its reproduction required the creation of something new. But this new was, in general, something well-known, predetermined by the same tradition. It was primarily about the physical novelty of buildings that replaced the old, decaying ones. It corresponded to the logic of the natural change of generations as well as temporal cycles.

At the same time, there was also the concept of eternity, not subject to the flow of time.

\section{THE IDEAL OF ETERNAL YOUTH}

In Domostroy, there are instructions to maintain a constant, stable order, firmness and cleanliness in every household: "... everything should be firm, and strong, and should not be rotten, and should not pile up, both on the roof and on the ground, - no yard and no household should be of old age, as all should be new" [5]. And in another fragment, it is said: "... one always enters a good house, as he enters Heaven " [5].

This is how the essence of Paradise was understood in the XVI century: stability, order, prosperity, and physical novelty, immunity to the decay of structures and things. This is what a decent Christian should strive for. Domostroy was created as a set of rules of a patriarchal but transformed by Orthodoxy, idealized family life.

This gives grounds to speculate about the replacement of the ancient cyclical perception of time by a linear, unidirectional one, imbued with Christian eschatology. Many respected historians of medieval culture write on this. The question is fundamental, however, it cannot be simplified.

The fact is that in pagan times there were concepts of eternity and immortality. The monumental cult architecture corresponded namely to these concepts. It is known how careful the Egyptians tried to preserve the bodies of their dead. According to Christian views, righteous men could become saint elders, awarded with eternal life in Heaven. Their relics became imperishable and were revered from generation to generation. In general, the cult of the dead for centuries assumed the continuation of life after the earthly death.

It is impossible not to note in connection to this topic the special worship in ancient times of those constellations that circled near the North Pole, and never crossed the horizon. Almost all peoples of the Northern hemisphere considered them to be the symbols of immortality, indicating the location of the halls of the heavenly gods [6].

An eternity in mythological consciousness was not always identified with infinity. Each creature has its own time - short or long. Russian fairy tales tell that it is still possible to find the secret of the death of Koschei the Immortal. According to ancient Greek myths, the Olympic gods put an end to the rule of titans. However, they died not ultimately, being immortal by nature. Well known Hindu and Buddhist ideas tell us that this world itself will come to an end sometime. True happiness is to break out of the circles of birth and death and find nirvana. The New Testament Apocalypse, too, foreshadowed the coming of the end of times, the rolling up of the sky in a manner of a scroll, and the destruction of this earth. But it also encouraged people to enter a new world that would be truly perfect and unbreakable forever and ever.

The doctrine of the resurrection of the dead on the eve of the Last Judgment set people up for the return of their youth in reality and in the flesh. Not childhood, not adolescence, but the youth of an adult, thirty-yearold man, which is called "the prime of life". The further life of God's people in New Jerusalem was thought to be heavenly, pristine and infinite, together with the Lord Himself.

The ideal of eternal youth is absolutely beautiful in the Christian interpretation. But the pagan tradition brought a certain confusion to its perception. It is enough to remember magical fairy tales with their miraculous princesses, either enchanted and sleeping for hundreds of years, or appearing to be evil old witches or shapeshifting ghouls. It is not surprising that people were afraid of the charms of youth and beauty, as well as the immeasurable longevity of old men, which has already been noted above. It was important for them not to be deceived, not to fall into temptation.

Youth means bodily novelty, and consequently health, freshness, purity, the correctness of the construction and the beauty of the body, which has no flaws. These definitions can be applied to architectural constructions, first of all, which had a vital, sacred meaning. The cult of purity reigned such structures.

The traditional reverent attitude of the family to the household hearth, where the unquenchable fire had to be maintained, is indicative. It is appropriate to remember the ancient Roman priestesses of the community hearth - vestal maidens, which certainly were young virgins. The Romans worshipped Vesta, the goddess of the hearth, while the Greeks worshipped Hestia. There is no doubt that other peoples, including the Slavs, had similar chaste goddesses. There is ethnographic evidence on a strict prohibition to throw waste into the fire and to swear near to a furnace [3].

The fire was traditionally used to cleanse the earth from all sorts of filth [7]. From this point of view, fires were not perceived as tragic as they are nowadays. Renewal of the place of residence, its purification and re-consecration through all kinds of rites were extremely important. The fact that Grand Knyaz Vladimir, after he christened Russia, has ordered to 
build churches on places of pagan capitals is very indicative [8]. Thus, he did not renounce these places but decided to radically renew, to transform their ancient sacral importance.

The history is full of examples of complete desolation of settlements, whose inhabitants moved to new lands. And it was extremely important not to make the wrong choice of place. It must be said that a place that was not occupied, clean, untainted by anyone was especially valued. This is evidenced by the characterization of the place chosen by the Tver Knyaz Boris Alexandrovich for the construction of a new city, given in the "Word of Praise" by the monk Foma: "And God gave him a place, no other dug or poured. ...but made by God, for the city to come into being..." [9].

The virgin purity of nature was of paramount importance for the foundation of monasteries in "wastelands" - away from the cities and villages filled with sins. In connection to this, it is worth remembering the legends about how God created a smooth, fertile land, and the Devil strived to spoil it [10]. It follows that for a righteous life the man should find clean, sacred places. But it also makes sense to purify those which are unclean. The construction of more and more new churches and monasteries helped the visible transformation, enlightenment, and healing of the earth, and so the country which not without a reason in due course began to be called "Sacred Russia".

\section{NEW AS UNSEEN}

Although the people who tended to live "the old way" avoided innovations and strangers, they had traditions of hospitality, and a keen interest in the tales of travelers, overseas goods and fabulous curiosities. Domostroy strictly forbade to bring bad information into the house and "to take out the rubbish from the hut" in order to preserve communal peace and tranquility [5]. Good news, as well as acquisitions that enriched the family, were always welcome. Many omens and fortune-telling signs are known, which determined whether something led to success or loss. The birth of children, the breeding of cattle, the increase in material wealth - all these are good signs. It follows that traditional culture was not closed within the framework of the known, but aimed at the appearance and acquisition of something new, including unusual, but necessarily useful.

If we remember the conquering campaigns or raids, it becomes obvious how fearlessly and with lust the winners collected and shared their prey. They had no fear of strangers, aliens and uncharted, as long as the higher powers promised them good luck. Military trophies from precious metals were often melted, but sometimes they were exhibited, as it was, for example, with the pagan statues brought by Knyaz Vladimir Svyatoslavich from Korsun (Chersonesus), which decorated the square in front of the main church in already baptized Kiev.

Speaking about the acquisition of something unseen, it is impossible not to mention the trade exchange, which was carried out for centuries between different, often distant lands. It had its traditional order, aimed at maintaining justice and security. It was not without reason that churches were necessarily placed on the trade squares. Therefore, it was possible to safely bring the overseas goods into the house with peace of mind, if they seemed good and useful. New things also appeared in the form of gifts, including exotic ones. Of course, fears could arise about the evil temptation contained in such exotic, but there always has been the personality of the giver behind the gift, and it must have been known and respected. Accidentally found things were considered dangerous.

It was also considered dangerous to intrude to the world of posad, and even more - to the house of a stranger. Being outside of the system of local connections, this unknown man was unpredictable and free in his will, which could turn out to be bad. That was the meaning of the customs of hospitality: to welcome a stranger, to put him in a place of honor, to feed him at a common table, to wash him in a bathhouse, to put him into bed - all in order to make him feel comfortable and adapted, to engage in friendly relations. Otherwise one could make the worst enemy "not from this world" with all the consequences that follow from this.

It follows from the above that in a kind manner many innovations in architecture and artistic crafts could easily be transferred from one country to another. But only to the extent of their attractiveness and demand. Construction crew often consisted of people who came from outer lands, no one knows from where, although someone certainly had to vouch authoritatively for the main master. People were always wary of the builders, as well as stove-makers, potters and other craftsmen, as they knew the secrets on which the future well-being of the owners who hired them depended. While masters could accidentally do something wrong, they also could deliberately harm and damage the new house [11]. It is clear that foreign carpenters or bricklayers carried some of their constructive and decorative techniques, which became injections of new for local traditions.

It is well known that European architects were invited to Russian cities, after which the architecture became much different. It does not mean at all that customers intended to break the covenants of fathers and grandfathers and to depart from them. No, they sought only to improve the building tradition, in order to come closer to achieving the ideal enclosed in it. 
Considering the reconstruction of the Moscow Kremlin in the late XV - early XVI centuries in such a way makes it clear that the Italian architects, with all their ambitions and privileges, served only as masterful performers of the Grand Ducal task, which was absolutely indifferent to the origins of the features that would appear in Moscow, whether they would be Italian or from any other European school of architecture. This task was aimed at the revival and proclamation of their own, native culture, just with the participation of the foreigners.

Renaissance variations of Russian churches, chambers, and fortresses were successful, they were to the taste of Muscovites and became models for further use. But there were cases when there was a completely different attitude to architectural innovations. So, a century later in the same Kremlin, on the so-called Vzrub - a fortified southern slope of Borovitsky Hill False Dmitry during the eleven months of his reign has managed to build his own chambers, which, became a new prominent architectural dominance of Moscow. However, these chambers were called "fornicatory" and have been immediately demolished as soon as notorious impostor accused of relations with unholy forces left.

This example shows how important it was to be vigilant and sensitive in order to recognize in time where the good and where the evil was, where the beauty is true and where the beauty is false. It is clear that if the tsar, supported by the Poles, had taken the Moscow throne, his chambers would have remained intact, as well as the model of Gehenna, arranged by his command behind the Moscow River [12]. Nevertheless, the people, indeed, were characterized by suspicion and distrust of everything new, especially foreign and nonorthodox. So, the "voice of the people" is called the "voice of God" not without a reason.

Moscow was destined to become a qualitatively new, royal capital of the huge Russian State, which not only restored its former possessions but also joined the boundless territory of the disintegrated Golden Horde. The proclamation of Moscow as the Third Rome - the New Tsargrad meant the transfer of the greatness and glory of all the former world kingdoms into it, by the will of God. Now we are not talking about the traditional resemblance of the younger city to the older one, but about the creation of a completely new, better, truly Orthodox city. The Russian Chronograph of 1512 formulates this idea, borrowed from the Greek Chronicle of Constantine Manasseh: "Our new Rome, Tsargrad, blossoms and grows, strengthens and rejuvenates, so let it grow to the end [of days]. "Long live, Tsar!" [13].

Such ideological and architectural-artistic transformation of Moscow and the whole Russian State inspired people and stimulated creativity. But with all its uniqueness it has also been alarming. Already at the beginning of the XVI century, Neil Sorsky and his likeminded "non-possessors" dissociated themselves from Joseph Volotsky's supporters, who fought for the wealth and beauty of the church. And in the second half of the XVII century, a church schism happened, which revealed a fierce rejection by the advocates of old of the innovations coming from the power. Fabulously lush, shining patterns, which its creators boasted about, was condemned by the Old Believers as a devilish motley and the charm of overly-ambitious souls, peculiar to the Last Days.

\section{Conclusion}

Traditional culture did not reject innovation by any means. The emergence of innovation was foreseen and even obligatory, but only at a certain time, at a certain place and to a certain extent. Oldness and novelty formed an inseparable pair of antinomies. They were to replace each other in accordance with the cyclical course of time and life itself. The gradual transition from one extreme to the other was essential. Between infancy and deep old age, there was the "golden middle" - the time of maturity and the flourishing of forces. These human characteristics are applied to architectural structures and explain a lot in their traditional structure and existence.

The concept of youth as physical novelty, purity, durability, and beauty served as an ideal against the destructive decrepitude. This ideal is conjugated with eternity, holiness and immortality. The pursuit of it was also embedded in tradition.

Special excitement was caused by the uniqueness, the unseenness of the new, appearing from foreign existence. The contact with another world was dangerous but necessary for a better life. It demanded dexterity and heroism. The task was to take possession of a fabulous jewel and remove the spell from it, to make it own, native, kind, and faithful.

The end of the Russian Middle Ages was marked by an extraordinary creative enthusiasm associated with the transformation of Moscow into a new royal and faithful Orthodox capital of the world. Architecture began to be unbridledly enriched by all kinds of borrowings and artistic fantasies that marked the renewal and transformation of the world. However, there were many people who saw a manifestation of sinful pride and devilish intrigue in it. With such anxiety and bitterness, Russian society fell in the church schism, met the New Age, full of even greater innovations, which eclipsed and irreparably transformed the deep medieval traditions. 


\section{References}

[1] A. K. Bayburin, The Ritual in traditional culture. Structural and semantic analysis of East Slavic rites (Ritual v traditsionnoy kulture. Strukturno-semanticheskiy analiz vostochnoslavyanskih obryadov). St. Petersburg: Nauka, 1993, pp. 38-123, 53, 102103 [in Russian].

[2] V. Y. Propp, The historical roots of a fairy tale (Istoricheskie korni volshebnoy skazki). Leningrad: LGU, 1986, pp. 53-56 [in Russian].

[3] A. N. Afanasyev, Slavic mythology (Slavyanskaya mifologiya). Moscow: Eksmo; St. Petersburg: Midgard, 2008, pp.470-535, 652 [in Russian].

[4] V. Kravchenko, Indigenous population and its remnants in Ukraine - on the material, collected on the Right Bank, Fire, Issue $1 / 3$ (Pervisne gromadyanstvo ta yogo perezhitki na Ukraini - materiyal, zibranits na Pravoberezhzhi, Vogon, Vypusk 1/3). Kyiv: Derzhavne vidavnitstvo Ukraini, 1927, p.171 [in Ukrainian].

[5] V. V. Kolesov, Domestic Order (Domostroy). Moscow: Sovetskaya Rossiya, 1990, pp.63-64, 68, 80 [in Russian].

[6] N. J. Lockyer, The dawn of astronomy. Planets and stars in the myths of ancient peoples (Rassvet astronomii. Planety i zvezdy v mifah drevnih narodov). Moscow: Tsentrpolygraph, 2013, pp.153-163 [in Russian].

[7] A.G. Toporkov, Fire: Slavic mythology. Encyclopedic dictionary (Ogon: Slavyanskaya mifologiya. Entsiklopedicheskiy slovar). Moscow: Ellis Luck, 1995 [in Russian].

[8] M.D. Prisyolkov, Complete collection of Russian chronicles, vol. 38 (Polnoe sobranie russkih letopisey, tom 38). Leningrad: Nauka, 1989, p.54 [in Russian].

[9] L.A. Dmitryev, D.S. Likhachev, Monuments of ancient Russian literature: The second half of the XV century, The word of praise by the monk Foma (Pamyatniki literatury Drevney Rusi: vtoraya polovina XV veka, Inoka Fomy Slovo Pohvalnoe). Moscow: Khudozhestvennaya literatura, 1982, p.294 [in Russian].

[10] V.V. Milkov, S.V. Milkova, Ancient Russia: crossing of traditions. Apocryphal expression of mythological views (Drevnyaya Rus': Peresechenie traditsiy. Apokrificheskoe vyrazhenie mifologicheskih vozzreniy). Moscow: Scriptorium, 1997 [in Russian].

[11] S.V. Maximov, Impure, unknown and godly power (Nechistaya, nevedomaya i krestnaya sila). Moscow: Kniga, 1989, pp.113117 [in Russian].

[12] B.A. Uspensky, Artistic language of the middle ages. Tsar and impostor: imposture in Russia as a cultural-historical phenomenon (Hudozhestvennyy yazyk srednevekovya. Tsar i samozvanets: samozvanchestvo v Rossii kak kulturnoistoricheskiy fenomen). Moscow: Nauka, 1982, pp.214-217 [in Russian].

[13] Russian Chronograph, edition of 1512. Complete collection of Russian chronicles, vol. 22, part 1, (Russkiy Khronograf redaktsii 1512 goda. Polnoe sobranie russkih letopisey, tom 22, chast' 1). St. Petersburg, E. Pratz typography, 1911, p.285 [in Russian]. 